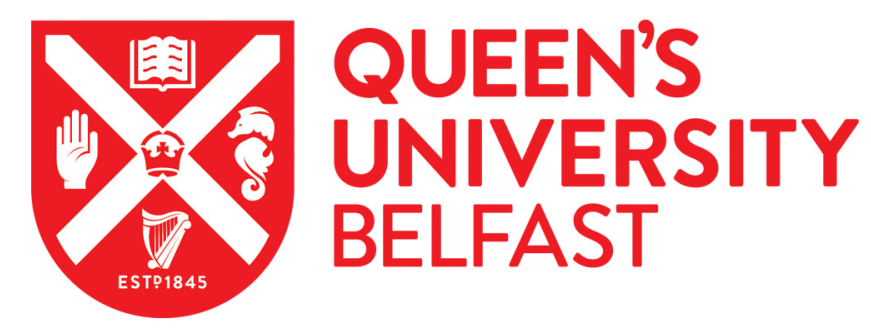

\title{
From empathy to action: Can enhancing host-society children's empathy promote positive attitudes and prosocial behaviour toward refugees?
}

Taylor, L. K., \& Glen, C. (2019). From empathy to action: Can enhancing host-society children's empathy promote positive attitudes and prosocial behaviour toward refugees? Journal of Community and Applied Social Psychology, 29(5). https://doi.org/10.1002/casp.2438

Published in:

Journal of Community and Applied Social Psychology

Document Version:

Peer reviewed version

Queen's University Belfast - Research Portal:

Link to publication record in Queen's University Belfast Research Portal

Publisher rights

2019 John Wiley \& Sons, Ltd.

This work is made available online in accordance with the publisher's policies. Please refer to any applicable terms of use of the publisher.

\section{General rights}

Copyright for the publications made accessible via the Queen's University Belfast Research Portal is retained by the author(s) and / or other copyright owners and it is a condition of accessing these publications that users recognise and abide by the legal requirements associated with these rights.

\section{Take down policy}

The Research Portal is Queen's institutional repository that provides access to Queen's research output. Every effort has been made to ensure that content in the Research Portal does not infringe any person's rights, or applicable UK laws. If you discover content in the

Research Portal that you believe breaches copyright or violates any law, please contact openaccess@qub.ac.uk. 
Running Header: CHILD PROSOCIAL BEHAVIOR TOWARD REFUGEES

From empathy to action: Can enhancing host-society children's empathy promote positive attitudes and prosocial behavior toward refugees?

Laura K. Taylor, University College Dublin and Queen's University Belfast

Catherine Glen, Queen's University Belfast

Correspondence should be addressed to Catherine Glen, School of Psychology, 18 - 30

Malone Road, Belfast BT9 5BN, Northern Ireland. E-mail: glen.catherine@gmail.com.

Acknowledgements: We would like to thank the many schools, parents, and children who participated in this research. In addition, we would like to recognize the contributions of Dr. Jocelyn Dautel, Dean O’Driscoll, and Lynn Muldrew who participated in the creation and data collection of this research project. The research was carried out as part of the Helping Kids! lab (helpingkidsqubblog.com), and supervised by Dr. Taylor, fulfilling the requirements of Glen's MSc dissertation, thanks to the financial support in 2016-17 of the Rotary International and Capital Rotary Club, Rotary District 7770, with follow-up funding in 2018. There are no conflicts of interest in the preparation or publication of this paper. 


\title{
From empathy to action: Can enhancing host-society children's empathy promote positive attitudes and prosocial behavior toward refugees?
}

\begin{abstract}
Over half of refugees are school-aged children. In host communities, children's attitudes and behaviors are important for integration of refugee children. This study examines the empathyattitude-action model in middle childhood ( $\mathrm{N}=94,8$ to 11 years old). In both the experimental and control conditions, children were introduced to a (fictional) refugee, and told he/she would be moving to their school. The experimental condition also listened to a storybook about the child's refugee experience. Empathy, outgroup attitudes and prosocial behavior toward the incoming child, and refugees as a group, were measured. Although mediation was not supported, the storybook condition reported more empathy and helping intentions, and attitudes predicted helping intentions but not giving to refugees. Results highlight how hostsociety children can welcome refugees.
\end{abstract}

Keywords: empathy, attitudes, prosocial behavior, refugees, children 
In response to an increase of refugees and migrants across the world, scholars have begun to identify key factors to help newcomers, particularly children, integrate into host societies. For example, attitudes and willingness among host society peers to assist in the transition are critical to fostering a nurturing environment for school-aged refugees (Fazel, 2015; Fazel, Reed, Panter-Brick, \& Stein, 2012). Previous research with adults (Batson, Chang, Orr, \& Rowland, 2002) and children (Aboud \& Levy, 2000; Nesdale, Griffith, Durkin, \& Maass, 2005) suggests that enhancing empathy may have implications for intergroup and prosocial behaviors among majority group members. Given that integration has implications for positive intergroup relations (Esses, Hamilton, \& Gaucher, 2017), the current paper focuses on the important role that host-society children play. We develop and test a novel approach to inducing empathy toward an individual refugee child, which can in turn promote children's positive attitudes and prosocial behaviors toward refugees in general. Informed by the recent special issue in this journal on the topic, this paper contributes to the fields of community and applied social psychology by focusing on the individual actions that children can take, or not, in response to the inclusion-advocacy challenge (Sambaraju \& McVittie, 2017). This area of research is essential to help policymakers and practitioners attend to the needs of over 11 million school-aged refugees (UNHCR, 2018).

\section{Empathy-Attitudes-Action Model}

Among adults, inducing intergroup empathy can improve outgroup attitudes and promote prosocial behavior across group lines (Batson et al., 2002). Batson proposes four steps in this 'empathy-attitudes-action' (EAA) model, in which empathy, or an "otheroriented emotional response congruent with the perceived welfare of another," (Batson et al., 2002, p. 1856), is stimulated by perspective taking, or the "cognitive capacity to consider a situation from the point of view of another person" (Newman \& Newman, 2015, p. 248). The EAA process unfolds as an individual: (a) adopts the perspective of another person in need, 
and experiences increased empathetic feelings for that person, which (b) leads to an increased valuing of the person's welfare and, in turn, (c) positive attitudes toward the outgroup as a whole; those outgroup attitudes underlie (d) an increased motivation to help other members of the outgroup, given the need is salient to their group membership (Batson et al., 2002).

Extending this logic, the current study examines the EAA model in middle childhood. Between ages 7 to 11, cognitive skills increase, which promote deeper perspective taking (Hoffman, 2000). During this period, children also begin to display sophisticated forms of empathy which have an impact on their interpersonal prosocial behaviors (Abrams, Van de Vyver, Pelletier, \& Cameron, 2015). However, by this age, children are also able to differentiate between ethnic groups based upon physical cues, and members of the ethnically dominant group consistently display negative attitudes toward members of minority ethnic groups (see review by Aboud, 1988). Moreover, children also demonstrate consistent intergroup biases in empathy for and prosocial behavior toward others based upon group membership (Abrams et al., 2015; Eisenberg, Eggum, \& Di Giunta, 2010). Given that refugees are often resettled in a third country with vastly different cultural and ethnic compositions among the majority of inhabitants, they are often considered an ethnic minority or outgroup; this categorization is critical when considering attitudes and behaviors of the host-society children. Therefore, we focus on middle childhood as a time when children have increased and nuanced cognitive and emotional capacity, as well as the ability to distinguish between ingroup and outgroup members. Examining the EAA model within this age group has the potential to shed new light on ways to help welcome refugee children to their new host societies.

\section{Inducing Intergroup Empathy}

Testing the EAA model requires the successful induction of intergroup empathy. As empathy requires the perception of a person in need (Batson, 2011), this need must be 
communicated to participants. Narratives, displayed via storybooks, novels, etc. are commonly used to induce empathy (Beelmann \& Heinemann, 2014; Soble, Spanierman, \& Liao, 2011), as they allow the participant to see a situation from another person's perspective (Keen, 2006). Moreover, inducing empathy via storybooks or videos in which others are in need increases children's willingness to share resources with or offer practical support to the individual (Williams, Driscoll, \& Moore, 2014). However, such research has traditionally been conducted in the interpersonal domain. Given that group membership shapes empathetic responses (Abrams, Rutland, Cameron, \& Marques, 2003; Sierksma \& Thijs, 2017), it is imperative to evaluate these processes within the intergroup domain (Turner \& Brown, 2008). Batson and others have demonstrated that group-based boundaries may be overcome by actively taking the perspective of the outgroup member in need (Shih, Wang, Trahan Bucher, \& Stotzer, 2009; Todd \& Galinsky, 2014). Thus, the present study will induce children's empathy toward refugees through perspective taking during a storybook narrative.

\section{Empathy and Prosocial Behaviors}

The EAA model suggests that empathy is linked to prosocial behaviors through attitudes. Previous research has found support for each path of this mediational model. First, empathy promotes both actual and intended prosocial acts (Batson, 2011), or "voluntary behavior intended to benefit another" (Eisenberg et al., 2010, p.146), such as sharing resources, helping, or comforting (Schroeder \& Graziana, 2015). Actual prosocial behavior is an action that has been executed, whereas intended prosocial behavior is an expression of a willingness to engage in an action at a future time or in a hypothetical situation (Ajzen \& Fishbein, 1977). Intentions representing realistic, rather than hypothetical, situations are considered more proximate to actual behavior (Ajzen \& Fishbein, 2005).

Decades of research have demonstrated that empathy is a driving force for both actual and intended prosocial behaviors across group lines (Davidov, Vaish, Knafo-Noam, \& 
Hastings, 2016; Eisenberg et al., 2010). Among children, empathy has been linked to prosocial behavior toward an individual outgroup member in a minimal group paradigm (Abrams et al., 2015). Inducing empathy through an imagined friend group was also effective at overcoming ingroup biases in children's helping intentions (Sierksma, Thijs, \& Verkuyten, 2015). These studies offer converging evidence that empathy can promote prosocial behavior toward an individual outgroup member.

However, while Batson found that empathy for a single outgroup member not only increased readiness to help that individual, but also to help their group as a whole (Batson et al., 2002), these findings have not been replicated with children. Developmentally, there is evidence that by middle childhood a growing sense of group dynamics and moral understanding will enable children to make this extension. For instance, children have the capacity to understand the concept of group-based need and inequality (Elenbaas \& Killen, 2016). This understanding has recently been linked to prosocial behavior whereby children seek to rectify injustices through resource allocation (Elenbaas \& Killen, 2016; Rutland \& Killen, 2017). If children act in response to group-based need, it is plausible that inducing empathy based on group membership could transfer into a willingness to help the group as a whole.

\section{Empathy and Attitudes}

Among adults, there is evidence for the 'empathy-attitude' effect, whereby empathy induced by taking the perspective of one outgroup member improves attitudes toward that individual and their group as a whole (Batson et al., 1997; Stephan \& Finlay, 1999). Correlational studies suggest that empathy may also play a role in shaping outgroup attitudes among children. For instance, among Anglo-Australian children ages 5 to 12 years old, trait empathy predicted liking for ethnic outgroup members, with more empathetic children expressing greater liking (Nesdale et al., 2005). In this setting, greater liking may be 
attributed to children's understanding of social inequities and compassion for those who have less favorable circumstances. In the United Kingdom (UK), a school-based intervention also found that children's empathy was correlated with liking of refugees (Turner \& Brown, 2008). Moreover, intergroup empathy mediated the relation between contact and positive outgroup attitudes among children in Italy (Vezzali, Hewstone, Cappoza, Trifiletti, \& Di Bernardo, 2017). In this study, children with higher levels of empathy had more positive orientations toward immigrants as a whole. Yet, interventions with children aiming to improve outgroup attitudes, including specifically toward refugees (Cameron, Rutland, Brown, \& Douch, 2006; Turner \& Brown, 2008), have had moderate success; 55\% of studies reported improvements in attitudes and $25 \%$ reported changes in peer relations (Aboud et al., 2012). With a caveat for how difficult it may be to change outgroup attitudes, these studies support an empathy-attitude effect in children, specifically toward minority outgroups. Improving attitudes, however, may not be sufficient if it does not translate into meaningful action.

\section{Attitudes to Action}

In the EAA model, the final step is that outgroup attitudes predict helping outgroup members. Although attitudes may serve as an antecedent for subsequent behavior (see Ajzen \& Fishbein, 2005), cost-benefit considerations may influence decisions to engage, or not, in a specific behavior. For instance, despite holding a favorable view of another, a person may choose not to offer assistance if it comes at a cost to themselves or others (Batson, 2011). In addition, while intergroup research has historically focused on negative outgroup attitudes (e.g. prejudice and discrimination) linked with negative outgroup behaviors (e.g. aggression or violence; see Genthner, Shuntich, \& Bunting, 1975; Genthner \& Taylor, 1973; Zomeren, Fischer, \& Spears, 2007), more recent studies examine positive pathways. Taylor et al. (2014), for instance, found that positive outgroup attitudes were associated with self-reported 
outgroup prosocial behavior over time among young people in a post-accord society. General attitudes toward immigrants were also predictive of intended prosocial behavior toward that group among majority children (Vezzali, Cadamuro, Versari, Giovannini, \& Trifiletti, 2015). These recent studies with children and youth suggest that promoting positive outgroup attitudes can promote prosocial behavior; yet, there is still ambiguity about the beneficiaries of such actions, that is, helping individual outgroup members or helping the group as a whole.

\section{Current Study}

Children's attitudes and behaviors do not occur in a vacuum, but are influenced by the people and structures around them (Pauker, Williams, \& Steele, 2016). To understand the broader context of the current study, Northern Ireland (NI) is a relatively homogeneous population of two million. In 2011, NI was the least ethnically diverse region in the UK; $98.2 \%$ of the population identified as White (Russell, 2013), and 89\% was born in NI, with the majority of those born elsewhere relocating from the European Union. Thus, the vast majority of children in NI do not have contact with ethnic outgroup members in their daily lives. Therefore, children arriving from Syria as part of the Vulnerable Persons Relocation Scheme, which will resettle at least 2,000 Syrian refugees to NI (Home Office, 2015), would predominantly be from a different ethnic, religious, and linguistic background than the general NI population, and thus, would be a visible minority group in a school context. Despite the relative ethnic homogeneity in NI, group membership, largely tied to ethnopolitical (Catholic or Protestant) background, is particularly salient, even among young children (Connolly, Smith \& Kelly, 2002).

Against this backdrop, the current study examined the applicability of the EAA model during middle childhood, specifically in promoting children's prosocial behavior toward incoming refugees. The study aimed to evaluate the effectiveness of inducing empathy, assess the impact of induced empathy on positive outgroup attitudes and prosocial behavior (toward 
an individual and their group), and test if outgroup attitudes mediate the relation between empathy and prosocial behavior across conditions.

\section{Methods}

\section{Participants}

Ninety-four children, 8 to 11 years old $(M=9.29, S D=.96)$, from five primary schools participated in Spring 2017, the majority of whom (91.5\%) were born in NI. Principals provided consent for their primary schools to participate. Parental information letters and consent forms were sent home to students in grades 4 through 7, in which children are approximately 7-8 through 10-11 years old, respectively; children with parental consent also provide assent prior to participating. Participants were tested individually by a trained researcher for approximately 15 minutes in a quiet area of the building during normal school hours. Children were given a certificate of participation and a small prize (e.g. pencil, notebook, or sticker) as compensation; none was given to parents, principals, or schools. The study was approved by the Ethics Committee at Author Identifying University, and materials can be found on Author Identifying Web Site.

\section{Apparatus and Materials}

Storybook. A 7-page picture book was adapted from a true story depicted in a German children's book, Bestimmt wird alles gut (Everything Will Be Alright) by Kristen Boie (Glen, Taylor, \& Dautel, 2019; Appendix A). The story follows the protagonist, Mohammed/Ayeesha, from pre-war life in Syria to a refugee camp in Germany, where they learn their family will be moving to NI. The story was delivered simultaneously in writing and pre-recorded audio (approximately 2 min 30 seconds).

\section{Procedures}

Participants were randomly assigned to one of three conditions: control (information only/no story) and two story conditions (low or high empathy). 
Meet Mohammed/Ayeesha. Using a photo, all participants were introduced to a gender-matched child, Mohammed/Ayeesha (M/A), and told that he/she was Syrian refugee. A child-friendly explanation of why people become refugees was provided (Appendix B). Then, a map and small printed caricatures of a boat, footprints, train, and airplane were used to show the journey typically traveled from Syria to NI (Appendices E and F). Next, participants were informed that $\mathrm{M} / \mathrm{A}$ and his/her family would be moving to NI and he/she would be joining their school.

Participants in the control condition then proceeded directly to the measures.

Empathy induction for low- and high-empathy story conditions. Participants in both story conditions were told that they would be listening to a true story about M/A's life. Those in the low-empathy condition were asked to pay attention to story details; those in the high-empathy story condition were asked to pay attention to how M/A was feeling. After each page, participants were asked questions to reinforce these areas of attention (e.g. low empathy: 'What did M/A eat while on the boat?'; high empathy: 'How do you think M/A felt when he/she was on the boat?') (Appendices C and G).

Participants in the story conditions then proceeded to the measures.

\section{Measures}

Empathy. After learning about refugees (control condition) or the story (experimental conditions), a single-item measure was adapted from Williams et al. (2014) which asked children how they felt; participants responded on a 4-point Likert-type facial affective scale with responses ranging from 4 (awful), 3 (not really good), 2 (really good) to 1 (brilliant) (Appendix H). Higher scores indicated more empathy.

Helping intentions. Adapted from Vezzali et al. (2015), participants responded to two specific, realistic helping settings: 'How much time do you want to help M/A during lunch' and 'How much time do you want to help M/A after school'. Responses were recorded 
using a 5-point Likert-type scale of progressively shaded clocks: 0 (none of the time), 1 (a little time), 2 (some of the time), 3 (most of the time) and 4 (all of the time) (Appendix I). Higher scores indicated intending to spend more time helping.

Resource donation. Participants were asked to donate seven $£ 1$ coins across three groups that needed help: Syrian refugee children, animal welfare, and nature charity. The two additional groups were chosen because of children's propensity to help animals (Triebenbacker, 1998) and select outdoors as the most popular area at school (Norðdahl \& Einarsdóttir, 2017). It was made clear that M/A would not receive any benefit. Groups were represented with photos and counterbalanced in a line in front of participants (Appendix J).

Outgroup attitudes. A 3-item scale measured children's outgroup attitudes (Nesdale et al., 2010). Questions assessed the degree that participants 'liked,' 'trusted,' and 'wanted to play with' Syrian refugee children. Responses were recorded using a 4-point Likert-type facial affective scale (e.g. 1 (I do not like them at all), 2 (I do not like them), 3 (I like them) to 4 (I like them a lot)); higher scores represented more positive outgroup attitudes.

\section{Debriefing}

Following these tasks, participants were told that although the book was based on a true story, the information about M/A coming to NI and their school was pretend.

\section{Results}

\section{Preliminary Analyses}

First, children's qualitative responses in both story conditions suggested that they clearly understood the task and were listening closely. Next, an independent samples t-test was conducted to compare the two experimental groups and found there were no significant differences in empathy $\left(\mathrm{t}(66)=-.17, p=.86 ; M_{p t}=3.32, S D=.78 ; M_{\text {fact }}=3.30, S D=.86\right)$. Therefore, these groups were combined in all subsequent analyses. A follow-up independent samples t-test found a significant difference between the story conditions and the no-story 
control (Table 1). This suggests that after hearing the story about the protagonist (M/A), children expressed greater empathy compared to the control condition in which they learned about refugees in general.

Second, a dependent t-test was conducted to compare responses on helping intentions across the two scenarios: lunch and after school. Children reported they would spend more time with $\mathrm{M} / \mathrm{A}$ at lunch than after school $\left(\mathrm{t}(93)=3.12, p<.01 ; M_{\text {lunch }}=3.22, S D=.84\right.$; $\left.M_{\text {afterschool }}=2.95, S D=.96\right)$. Therefore, these items were left as distinct measures.

Finally, an additional set of independent t-tests (Table 1) revealed more positive outgroup attitudes, at the trend level, and more time spent helping at lunch time in the story conditions compared to the control group. There were no statistically significant differences in helping M/A after school or the total amount donated to refugees in general between the two conditions. However, a one-way ANOVA and following contrasts revealed that children were more like to donate to refugees compared to animals $\left(\mathrm{t}(93)=8.55, p<.001 ; M_{\text {refugee }}=\right.$ $3.35, S D=1.13 ;$ Manimal $=1.87, S D=.72)$ or nature $(\mathrm{t}(93)=-.17, p<.001 ;$ Mnature $=1.79, S D$ $=.89)$.

Table 2 includes the bivariate correlations across the story and control conditions.

\section{Primary Analyses}

The EAA mediation model was tested in Mplus (Muthén \& Muthén, 1998-2011) across the full sample; manifest variables were used for all study variables (Figure 1). Empathy was entered as the primary predictor, and allowed to correlate with the control variables of school, child gender, and age; outgroup attitudes were entered as the mediator. The three prosocial outcomes, helping intentions at lunch and after school, and resource donation to refugees in general, were entered as exogenous variables and their errors allowed to correlate. Maximum likelihood estimation was used under the assumption that data are 
missing at random (Enders \& Bandalos, 2001). Model fit could not be estimated as it was a fully justified model.

The demographic controls were largely non-significant, except that older children reported being more likely to help after school $(\beta=.23, p=.029)$, and boys reported lower outgroup attitudes compared to girls $(\beta=-.37, p<.001)$. Empathy did not predict outgroup attitudes or the three prosocial outcomes; however, outgroup attitudes did predict helping intentions both at lunch and after school, but not overall donations to refugees. The two helping behavior outcomes were correlated $(r=.42, p<.001)$, but neither helping at lunch $(r=-.17, p=.16)$ or after school $(r=.16, p=.17)$ related to donations to refugees. Finally, the bootstrapped standard errors for the indirect effects suggested there was no significant mediation for any of the three outcomes (Figure 1).

\section{Discussion}

By investigating the empathy-attitudes-action (EAA) model in middle childhood, the current study examined if experimentally induced empathy via a storybook narrative predicted positive outgroup attitudes and prosocial behaviors toward refugees. Compared to the control condition, who learned about refugees and were introduced to a (fictional) child who would be joining their school, participants who also heard a real-life storybook expressed more empathy. This finding converges with studies that have successfully induced empathy through narrative (Batson et al., 1997; Shih et al., 2009; Sierksma et al., 2015; Todd \& Galinsky, 2014). Although empathy was not directly related to outgroup attitudes or prosocial behaviors, compared to the information-only control, children in the story condition also reported more positive attitudes toward refugees, at the trend level, and more helping intentions at lunch time. Diverging from adult studies (Batson et al., 2002), outgroup attitudes did not mediate the link from empathy to action. However, more positive outgroup attitudes predicted greater helping intentions toward $\mathrm{M} / \mathrm{A}$, both at lunch and after school. Although 
children donated more to refugees than to the other two groups in need, in the full model, this measure of actual behavior did not correlate with any of the other variables or demographic controls.

Following the EAA model (Batson, 2002), first, the story condition increased empathy, but not necessarily because of perspective taking (step a). Although children understood and followed instructions in the low- and high-empathy conditions, there were no significant differences in self-reported empathy. Although past research has demonstrated that perspective taking enhances children's emotional responses (Sierksma et al., 2015; Vescio, Sechrist, \& Paolucci, 2003), the low-empathy group was not impeded from experiencing a congruent emotional response. This finding may reflect that children this age can attend to what they perceive as a priority (Irwin-Chase \& Burns, 2000), in this case, how M/A was feeling, not only the story's details.

Second, while the link from empathy to concern for the welfare of M/A (step b) was not measured, the empathy-attitudes relation was not significant. Third, in the story condition there were more positive attitudes toward refugees as a group (step c), but not due to increased empathetic feelings for the protagonist. This finding of short-term increased attitudes with no change in empathy is consistent with previous studies among interventions with school children regarding refugees (Turner \& Brown, 2008). The disconnect between feelings of concern for refugees not aligning with other dimensions of support, such as calls for inclusion, has also been found among adults in the current refugee 'crisis' in Europe (Nightingale, Quayle, \& Muldoon, 2017). Future research should investigate other possible factors that may intervene between induced empathy and attitude change in children.

Finally, there was support for attitudes shaping prosocial behaviors (step d), but only toward $\mathrm{M} / \mathrm{A}$, not the group as a whole, suggesting the importance of measuring both intended and actual prosocial behaviors. For example, there were statistically significant differences in 
the time/domain of the realistic helping intentions (i.e. during vs. after school), which may reflect the cost-benefit considerations children make when deciding whether or not to act (Batson, 2011). There may be fewer 'costs' to helping at lunch, while already confined to the school site, than helping after school, which might be time reserved for close friends and family. However, children did favor refugees in their actual donations. By the age of eight, children's allocation decisions are influenced by the perceived need and merit of the recipient(s) (Moore, 2009; Schmidt, Svetlova, Johe, \& Tomasello, 2016). This suggests that children understood that individual needs of $\mathrm{M} / \mathrm{A}$ extended to his/her group and perceived refugee children to be more deserving than the other groups in need. To further tease out how refugee status influences resource allocation, different outgroups could be included as the alternative recipients of aid (e.g. ingroup members, non-refugee ethnic minorities, or other stigmatized outgroups, such as those with physical disabilities). Thus, future studies should continue to assess a range of types and targets of prosocial behaviors (O'Driscoll, Taylor, \& Dautel, 2018; Schroeder \& Graziana, 2015).

Regarding the other measures, a single item was used to assess empathy for M/A. The use of simple, multi-item scales designed for children could be improved in future research. Although previous studies found correlations between trait empathy and outgroup attitudes (Nesdale et al., 2005; Vezzali et al., 2015), the link between empathy induction and attitude change among children is largely unexplored (Eisenburg et al., 2010). Future research should include scales for both types of empathy to tease apart how dispositional factors, compared to emotional states, influence children's outgroup orientations. Moreover, due to the groupbased nature of the EAA model, future research should also explicitly assess empathy for the individual compared to empathy for the group as a whole (Barth \& Stürmer, 2016).

Measuring explicit outgroup attitudes could have been affected by social desirability or a ceiling effect, and the cultural context. The self-report nature may partially explain the 
link from attitudes to helping intentions; however, this only applied to helping at lunch and not after school. Future research could also consider children's implicit attitudes. In contrast to previous research with adults that focused on well-known, highly stigmatized outgroups, such as drug addicts or convicted felons (Batson et al., 1997), the current study examined the EAA model with a relatively novel outgroup (Shih et al., 2009). In NI's largely homogeneous society, children may not have had previous experience with refugees or other ethnic minority groups (ARK, 2015; McDermott, 2014). Future research should also assess the quality and quantity of any previous potential intergroup contact (Cameron et al. 2006), as well as look to replicate the model in more ethnically diverse settings. Testing the potential impact of EAA in other host societies is important because children's ethnic attitudes are shaped by their cultural contexts (Pauker et al., 2016).

These findings complement previous research in community and applied social psychology on factors underlying support for refugee resettlement in NI (Schulz \& Taylor, 2018) and Europe more widely (Goodman, Sirriyeh \& McMahon, 2017; Mahendran, 2017), particularly among children (Cameron et al., 2006; Vezzali et al., 2015, 2017). More specifically, by highlighting factors which support host-society children welcoming refugees, the results could inform programs within schools, resettlement agencies, and children's organizations and charities in NI, such as Barnardo's or the Northern Ireland Council for Ethnic Minorities (NICEM). For example, interventions could target both empathy and attitudes, while explicitly trying to lower the 'costs' of helping incoming refugees. These programs aimed at increasing the acceptance of and capacity to welcome newcomers will become increasingly important, as NI is poised to welcome 2,000 Syrian refugees over the next few years (McNulty, 2016). More broadly, the results can inform global efforts to prepare host communities to create warm and nurturing settings for refugee children 
worldwide. This type of evidence-based research is essential to overcome practical and structural practices that exclude refugees from host societies (Sambaraju \& McVittie, 2017). 


\section{References}

Aboud, F. E. (1988). Children and Prejudice. New York: Basil Blackwell Inc.

Aboud, F. E., Tredoux, C., Tropp, L. R., Brown, C. S., Niens, U., \& Noor, N. M. (2012). Interventions to reduce prejudice and enhance inclusion and respect for ethnic differences in early childhood: A systematic review. Developmental Review, 32(4), $307-$ 336. https://doi.org/10.1016/j.dr.2012.05.001

Aboud, F.E., \& Levy, S.R. (2000). Interventions to reduce prejudice and discrimination in children and adolescents. In S. Oskamp (Ed.), Reducing prejudice and discrimination. Mahwah, NJ: Lawrence Erlbaum Associates.

Abrams, D., Rutland, A., Cameron, L., \& Marques, J. M. (2003). The development of subjective group dynamics: When in-group bias gets specific. British Journal of Developmental Psychology, 21(2), 155-176.

https://doi.org/10.1348/026151003765264020

Abrams, D., Van de Vyver, J., Pelletier, J., \& Cameron, L. (2015). Children's prosocial behavioral intentions towards outgroup members. British Journal of Developmental Psychology, 33(3), 277-294. https://doi.org/10.1111/bjdp.12085

Ajzen, I., \& Fishbein, M. (1977). Understanding attitudes and predicting social behavior. New York: Eaglewood-Cliffs.

Ajzen, I., \& Fishbein, M. (2005). The influence of attitudes on behavior. In D. Albarracin, T. Johnson, \& M. Zanna (Eds.), The Handbook of Attitudes. London: Lawrence Erlbaum Associates.

ARK. Northern Ireland Life and Times Survey. (2015). Retrieved from www.ark.ac.uk/nilt/2015/minority_ethnic_people/

Barth, M., \& Stürmer, S. (2016). Comparison of the effects of individual and group-level perspective taking on intergroup reconciliation. Social Psychology, 47(6), 311-326. 
DOI:10.1027/1864-9335/a000285.

Batson, C. D. (2011). Altruism in Humans. New York: Oxford University Press.

Batson, C. D., Chang, J., Orr, R., \& Rowland, J. (2002). Empathy, attitudes, and action : Can feeling for a member of a stigmatized group motivate one to help the group? Personality and Social Psychology Bulletin, 28(12), 1656-1666.

https://doi.org/10.1177/014616702237647

Batson, C.D., Polycarpou, M.P., Harmon-Jones, E., Imhoff, H.J., Mitchener, E.C., Bednar, L.L., Klein, T.R., \& Highberger, L. (1997). Empathy and attitudes: Can feeling for a member of a stigmatized group improve feelings toward the group? Journal of Personality and Social Psychology, 72(1), 105-118. http://dx.doi.org/10.1037/00223514.72.1.105

Beelmann, A., \& Heinemann, K. S. (2014). Preventing prejudice and improving intergroup attitudes: A meta-analysis of child and adolescent training programs. Journal of Applied Developmental Psychology, 31(1), 10-24. https://doi.org/10.1016/j.appdev.2013.11.002

Cameron, L., Rutland, A., Brown, R., \& Douch, R. (2006). Changing children's intergroup attitudes toward refugees: Testing different models of extended contact, Child Development, 77(5), 1208-1219. https://doi.org/10.1111/j.1467-8624.2006.00929.x

Connolly, A., Smith, A., Kelly, B. (2002). Too young to notice? The cultural and political awareness of 3-6 year olds in Northern Ireland. Northern Ireland Community Relations Council. Belfast: Community Relations Council

Davidov, M., Vaish, A., Knafo-Noam, A., Hastings, P. (2016). The motivational foundations of prosocial behavior from a developmental perspective-evolutionary roots and key psychological mechanisms: Introduction to the special section. Child Development, 87(6),1655-1667. https://doi.org/10.1111/cdev.12639

Eisenberg, N., Eggum, N. D., \& Di Giunta, L. (2010). Empathy-related responding: 
Associations with prosocial behavior, aggression, and intergroup relations. Social Issues and Policy Review, 4(1), 143-180. https://doi.org/10.1111/j.1751-2409.2010.01020.x

Elenbaas, L., \& Killen, M. (2016). Children rectify inequalities for disadvantaged groups. Developmental Psychology, 52(8), 1318-1329. https://doi.org/10.1037/dev0000154

Enders, C. K., \& Bandalos, D. L. (2001). The relative performance of full information Maximum Likelihood Estimation for missing data in Structural Equation Models. Structural Equation Modeling: A Multidisciplinary Journal, 8(3), 430-457. doi:10.1207/S15328007SEM0803_5

Esses, V. M., Hamilton, L. K., \& Gaucher, D. (2017). The global refugee crisis: Empirical evidence and policy implications for improving public attitudes and facilitating refugee resettlement. Social Issues and Policy Review, 11(1), 78-123. https://doi.org/10.1111/sipr.12028

Fazel, M. (2015). A moment of change: Facilitating refugee children's mental health in UK schools. International Journal of Educational Development, 41, 255-261. https://doi.org/10.1016/j.ijedudev.2014.12.006

Fazel, M., Reed, R. V, Panter-Brick, C., \& Stein, A. (2012). Mental health of displaced and refugee children resettled in high-income countries: risk and protective factors. The Lancet, 379, 266-282. https://doi.org/10.1016/S0140-6736(11)60051-2

Genthner, R., Shuntich, R., \& Bunting, K. (1975). Racial prejudice, belief similarity, and human aggression. Journal of Psychology, 91, 229-34.

https://doi.org/10.1080/00223980.1975.9923947

Genthner, R., \& Taylor, S. (1973). Physical aggression as a function of racial prejudice and the race of the target. Journal of Personality and Social Psychology, 27(2), 207-210. https://doi.org/http://dx.doi.org/10.1037/h0034776

Glen, C., Taylor, L. K. \& Dautel, J. (2019). Promoting prosocial behavior toward refugees: 
Exploring the empathy-attitude-action model in middle childhood. In N. Bavlin \& D. Christie (Eds.), Children and Peace: From Research to Action. Switzerland: Springer Peace Psychology Book Series.

Goodman, S., Sirriyeh, A., \& McMahon, S. (2017). The evolving (re)categorisations of refugees throughout the "refugee/migrant crisis." Journal of Community and Applied Social Psychology - Special Issue: The European Union and The Refugee 'Crisis': Inclusion, Challenges, and Responses, 27(2), 105-114. https://doi.org/10.1002/casp.2302

Hoffman, M. L. (2000). Empathy and moral development: Implications for caring and justice. New York, NY, US: Cambridge University Press. http://dx.doi.org/10.1017/ CBO9780511805851

Home Office. (2015). Syrian Vulnerable Person Resettlement (VPR) Programme. London: Home Office

Irwin-Chase, H., \& Burns, B. (2000). Developmental Changes in Children's Abilities to Share and Allocate Attention in a Dual Task. Journal of Experimental Child Psychology, 77, 61-85. https://doi.org/10.1006/jecp.1999.2557

Keen, S. (2006). A Theory of Narrative Empathy. Narrative 14(3), 207-236. The Ohio State University Press. Retrieved August 12, 2018, from Project MUSE database.

Mahendran, K. (2017). Public narratives on human mobility: Countering technocratic and humanitarian refugee narratives with a "one-world" solidarity narrative. Journal of Community and Applied Social Psychology - Special Issue: The European Union and The Refugee 'Crisis': Inclusion, Challenges, and Responses, 27(2), 147-157. https://doi.org/10.1002/casp.2304

McDermott, P. (2014). Attitudes towards minority ethnic people and migrant workers 2014: Research update. Access Research Knowledge. Retrieved from http://www.ark.ac.uk/ publications/updates/update103.pdf 
McNulty, M. (2016). Refugees in NI 2016. Embrace NI. Retrieved from https://www. embraceni.org/wp-content/uploads/2012/09/Refugee-booklet-10.3.pdf

Moore, C. (2009). Fairness in children's resource allocation depends on the recipient. Psychological Science, 20(8), 944-948. https://doi.org/10.1111/j.14679280.2009.02378.x

Muthén, L. K., \& Muthén, B. O. (1998-2011). Mplus User's Guide. Sixth Edition. Los Angeles, CA: Muthén \& Muthén.

Nesdale, D., Durkin, K., Maass, A., Kiesner, J., Grif, J., Daly, J., \& Mckenzie, D. (2010). Peer group rejection and children's outgroup prejudice. Journal of Applied Developmental Psychology, 31, 134-144. https://doi.org/10.1016/j.appdev.2009.11.004

Nesdale, D., Griffith, J., Durkin, K., \& Maass, A. (2005). Empathy, group norms and children's ethnic attitudes. Journal of Applied Developmental Psychology, 26(6), 623637. https://doi.org/10.1016/j.appdev.2005.08.003

Newman, B., \& Newman, P. (2015). Development through life: A psychosocial approach (Twelfth Ed). Stamford, USA: Cengage Learning.

Nightingale, A., Quayle, M., \& Muldoon, O. (2017). “It's just heart breaking”: Doing inclusive political solidarity or ambivalent paternalism through sympathetic discourse within the "refugee crisis" debate. Journal of Community and Applied Social Psychology - Special Issue: The European Union and The Refugee 'Crisis': Inclusion, Challenges, and Responses, 27(2), 137-146. https://doi.org/10.1002/casp.2303

Norðdahl, K., \& Einarsdóttir, J. (2017). Children's views and preferences regarding their outdoor environment. Journal of Adventure Education and Outdoor Learning, 15(2), 152-167. https://doi.org/10.1080/14729679.2014.896746

O’Driscoll, D., Taylor, L. K., \& Dautel, J. (2018). Intergroup resource distribution among children living in segregated neighborhoods amid protracted conflict. Peace and 
Conflict: Journal of Peace Psychology, 24(4), 464-474.

http://dx.doi.org/10.1037/pac0000348

Pauker, K., Williams, A., \& Steele, J. R. (2016). Children's racial categorization in context. Child Development Perspectives, 10(1), 33-38. https://doi.org/10.1111/cdep.12155

Russell, R. (2013). Census 2011: Detailed Characteristics of Ethnicity and Country of Birth at the Northern Ireland Level. Northern Ireland Assembly. Belfast: Northern Ireland Assembly

Rutland, A., \& Killen, M. (2017). Fair resource allocation among children and adolescents: The role of group and developmental processes. Child Development Perspectives, 11(1), 56-62. https://doi.org/10.1111/cdep.12211

Sambaraju, R. \& McVittie, C. (2017). Editorial. Journal of Community and Applied Social Psychology - Special Issue: The European Union and The Refugee 'Crisis': Inclusion, Challenges, and Responses, 27(2), 99-104. https://doi.org/10.1002/casp.2306

Schmidt, M. F. H., Svetlova, M., Johe, J., \& Tomasello, M. (2016). Children's developing understanding of legitimate reasons for allocating resources unequally. Cognitive Development, 37, 42-52. https://doi.org/10.1016/j.cogdev.2015.11.001

Schroeder, D., \& Graziana, W. (2015). Oxford handbook of prosocial behavior. Oxford: Oxford University Press.

Schulz, M. \& Taylor, L. K. (2018). The processes underlying the quality contact with the primary out-group and in-group importance on support for the Syrian resettlement in a post-accord context. Peace and Conflict: Journal of Peace Psychology, 24(3), 306-314. http://dx.doi.org/10.1037/pac0000321

Shih, M., Wang, E., Trahan Bucher, A., \& Stotzer, R. (2009). Perspective taking: Reducing prejudice towards general outgroups and specific individuals. Group Processes \& Intergroup Relations, 12(5), 565-577. http://dx.doi.org/10.1177/1368430209337463 
Sierksma, J., \& Thijs, J. (2017). Intergroup helping: How do children see it? In E. Leeuwen \& H. Zagefka (Eds.), Intergroup Helping. New York: Springer International Publishing.

Sierksma, J., Thijs, J., \& Verkuyten, M. (2015). In-group bias in children's intention to help can be overpowered by inducing empathy. British Journal of Developmental Psychology, 33(1), 45-56. https://doi.org/10.1111/bjdp.12065

Soble, J. R., Spanierman, L. B., \& Liao, H. Y. (2011). Effects of a Brief Video Intervention on White University Students' Racial Attitudes. Journal of Counseling Psychology, 58(1), 151-157. DOI: 10.1037/a0021158

Stephan, W., Finlay, K. (1999). The role of empathy in improving intergroup relations. Journal of Social Issues, 55(5), 729-743. DOI: 10.1111/0022-4537.00144

Taylor, L. K., Merrilees, C. E., Goeke-Morey, M. C., Shirlow, P., Cairns, E., \& Cummings, E. M. (2014). Political violence and adolescent out-group attitudes and prosocial behaviors: Implications for positive inter-group relations. Social Development (Oxford, England), 23(4), 840-859. https://doi.org/10.1111/sode.12074

Todd, A., \& Galinsky, A. (2014). Perspective-taking as a strategy for improving intergroup relations: Evidence, mechanisms, and qualifications. Social and Personality Psychology Compass, 8(7), 374-387. https://doi.org/10.1111/spc3.12116

Triebenbacker, S. (1998). Pets as transitional objects: Their role in children's emotional development. Psychological Reports, 82(1), 191-200.

Turner, R. N., \& Brown, R. (2008). Improving children's attitudes toward refugees : An evaluation of a school-based multicultural curriculum and an anti-racist intervention. Journal of Applied Social Psychology, 38(5), 1295-1328. http://dx.doi.org/10.1111/j.1559-1816.2008.00349.x

UNHCR. (2018). What is a refugee? Retrieved from http://www.unhcr.org/refugeefacts/what-is-a-refugee/ 
Vescio, T. K., Sechrist, G. B., \& Paolucci, M. P. (2003). Perspective taking and prejudice reduction: The mediational role of empathy arousal and situational attributions. European Journal of Social Psychology. https://doi.org/10.1002/ejsp.163

Vezzali, L., Cadamuro, A., Versari, A., Giovannini, D., \& Trifiletti, E. (2015). Feeling like a group after a natural disaster: Common ingroup identity and relations with outgroup victims among majority and minority young children. The British Journal of Social Psychology, 54, 519-538. https://doi.org/10.1111/bjso.12091

Vezzali, L., Hewstone, M., Capozza, D., Trifiletti, E., \& Di Bernardo, G. A. (2017). Improving intergroup relations with extended contact among young children: Mediation by intergroup empathy and moderation by direct intergroup contact. Journal of Community and Applied Social Psychology, 27, 35-49.

https://doi.org/10.1002/casp.2292

Williams, A., Driscoll, K. O., \& Moore, C. (2014). The influence of empathic concern on prosocial behavior in children. Frontiers in Psychology, 5, 1-8.

https://doi.org/10.3389/fpsyg.2014.00425

Zomeren, M. Van, Fischer, A. H., \& Spears, R. (2007). Testing the limits of tolerance: How intergroup anxiety amplifies negative and offensive responses to out-group-initiated contact. Society for Personality and Social Psychology, 33(12), 1686-1699. https://doi.org/10.1177/0146167207307485 
Table 1. Independent t-tests on primary study variables across the control group $(n=26)$ compared to the story condition $(n=68)$.

\begin{tabular}{lccccccc}
\hline & Control Condition & \multicolumn{2}{c}{ Story Condition } & $\mathrm{t}$ & $\mathrm{df}$ & $p$ \\
& $M$ & $S D$ & $M$ & $S D$ & & & \\
\hline Empathy & 2.88 & 1.03 & 3.30 & 0.82 & 2.09 & 92.00 & 0.039 \\
Outgroup Attitudes & 3.22 & 0.57 & 3.41 & 0.41 & -1.80 & 92.00 & 0.075 \\
Helping Intentions - Lunch & 2.73 & 0.87 & 3.41 & 0.76 & -3.73 & 92.00 & $<.001$ \\
Helping Intentions - After School & 2.81 & 0.98 & 3.00 & 0.96 & -0.86 & 92.00 & 0.391 \\
Resource Allocation to Refugees & 3.38 & 1.10 & 3.34 & 1.15 & 0.18 & 92.00 & 0.860 \\
\hline
\end{tabular}


Table 2. Bivariate correlations among the child demographic characteristics and the main study variables for both the control and story conditions.

\begin{tabular}{|c|c|c|c|c|c|c|c|c|}
\hline & & 1 & 2 & 3 & 4 & 5 & 6 & 7 \\
\hline 1 & Male & - & 0.11 & -0.13 & $-.39^{* * *}$ & -0.15 & $-.31^{*}$ & 0.14 \\
\hline 2 & Age & 0.17 & - & 0.15 & 0.00 & $.25^{*}$ & 0.16 & 0.17 \\
\hline 3 & Empathy & 0.21 & 0.04 & - & 0.05 & 0.01 & 0.15 & 0.01 \\
\hline 4 & Outgroup Attitudes & -0.27 & -0.10 & 0.09 & - & $.42^{* * *}$ & $.42^{* * *}$ & -0.08 \\
\hline 5 & Helping Intentions - Lunch & -0.09 & 0.07 & 0.01 & $.64^{* * *}$ & - & $.59^{* * *}$ & -0.14 \\
\hline 6 & Helping Intentions - After School & -0.09 & -0.20 & 0.02 & $.68^{* * *}$ & $.50^{* *}$ & - & 0.12 \\
\hline 7 & Resource Allocation to Refugees & -0.27 & -0.01 & 0.04 & $.68^{* * *}$ & 0.32 & $.48^{*}$ & - \\
\hline
\end{tabular}

Note: $* p<.05 ; * * p<.01 ; * * * p<.001$. Control condition shown below the diagonal $(\mathrm{n}=26)$ and story condition shown above the diagonal $(\mathrm{n}=68)$ 
Figure 1. Bootstrapped mediation model demonstrating the indirect effect of empathy on helping intentions at lunch, after school, and donations to refugees, through outgroup attitudes for primary school children $(\mathrm{N}=94)$. Standardized coefficients are reported. Demographic controls of school, child age, and child gender are omitted for readability. Non-significant paths indicated with dashed lines. ${ }^{*} p<.05 ; * * p<.01 ; * * * p$ $<.001$

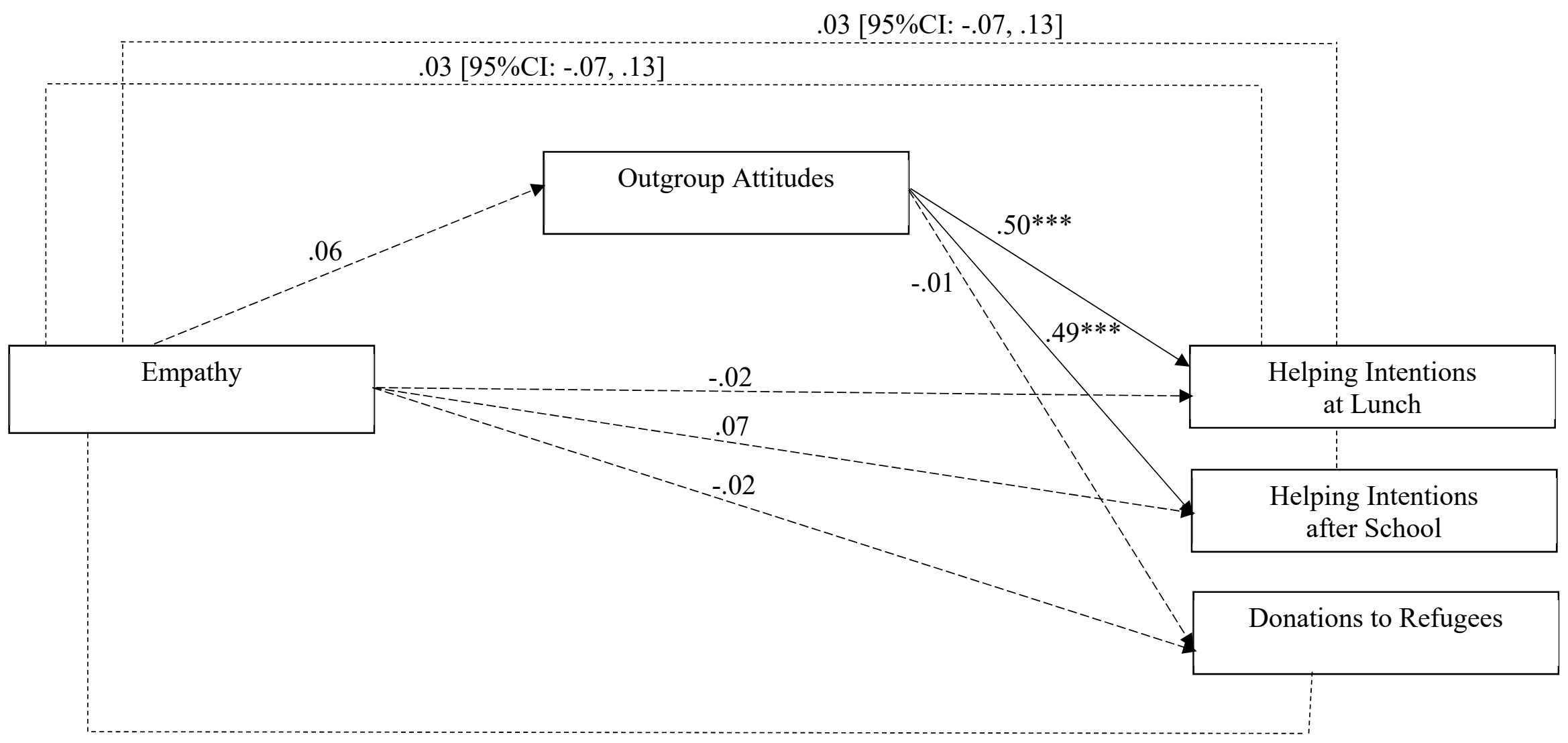

$.12[95 \% \mathrm{CI}:-.04, .07]$ 